\title{
Polymorphism at the dnaK locus of Brucella species and identification of a Brucella melitensis species- specific marker
}

\author{
A. CLOECKAERT, J-M. VERGER, M. GRAYON and O. GRÉPINET
} Laboratoire de Pathologie Infectieuse et Immunologie, Institut National de la Recherche Agronomique, 37380
Nouzilly, France

\begin{abstract}
The dnaK gene and surrounding sequences from reference strains of the six Brucella species were amplified by the polymerase chain reaction (PCR) with primers chosen according to the published sequence of the $B$. ovis dnaK gene and studied for polymorphism with nine restriction endonucleases. The restriction patterns were identical for all species with all restriction endonucleases tested except for $B$. melitensis strain 16M that showed a different pattern with $E c o R V$, consistent with the presence of a single site instead of two for the other Brucella species. The absence of the second EcoRV site for $B$. melitensis $16 \mathrm{M}$ was confirmed by DNA sequence analysis. The second EcoRV site in other Brucella species was located in a 12-bp segment, which was missing from the published dnaK sequence of $B$. ovis, between the stop codon of the dnaK gene and its putative transcription terminator sequence. The difference between $B$. ovis strain $63 / 290$ and $B$. melitensis $16 \mathrm{M}$ was due to an additional base-pair in $B$. melitensis $16 \mathrm{M}$. Subsequently, 71 other field, vaccinal and reference strains of the six Brucella species and their different biovars were studied for restriction fragment length polymorphism (RFLP) of the dnaK locus with EcoRV. The presence of a unique EcoRV site was specific to $B$. melitensis strains. Southern blot analysis of whole genomic DNA digested with $E c o R V$ and with the $d n a K$ gene used as probe also detected a distinct pattern for $B$. melitensis. These results indicate that both PCR-RFLP and Southern blot analysis of the dnaK locus can be used to distinguish $B$. melitensis strains from the other Brucella species and may be useful for typing and diagnostic purposes as well.
\end{abstract}

\section{Introduction}

Brucellae are gram-negative facultative intracellular bacteria that can infect man and many species of animals. Six species are recognised within the genus Brucella: B. abortus, B. melitensis, B. suis, B. ovis, B. canis and $B$. neotomae [1]. This classification is mainly based on differences in pathogenicity and in host preference [1]. Distinction between species and biovars is performed by differential tests based on phenotypic characterisation of lipopolysaccharide antigens, phage typing, dye susceptibility, $\mathrm{CO}_{2}$ requirement, $\mathrm{H}_{2} \mathrm{~S}$ production and metabolic properties [2].

It has been suggested on the basis of DNA homology ( $>90 \%$ for all species) that Brucella is a monospecific genus [3,4]. However, Allardet-Servent et al. [5] reported that restriction fragment-length polymorphism (RFLP) can be used to distinguish between species within the genus Brucella and supported host preference as a basis for classifying the brucellae.

Received 29 Nov. 1995; accepted 23 Jan. 1996.

Corresponding author: Dr A. Cloeckaert.
Recently, Fekete et al. [6] showed by arbitrarily primed polymerase chain reaction (AP-PCR) that Brucella strains can be distinguished according to the banding patterns of their amplified DNA on agarose gels. In addition, Grimont et al. [7] showed by Southern blot analysis of Brucella DNA, cut by Bam HI, with random cloned Brucella DNA probes, that the most frequently occurring biovars ( $B$. melitensis biovars 1 and $3, B$. abortus biovars 1 and 3 , B. suis biovar 2 and B. ovis) could be distinguished from each other. Species-specific markers have also been reported for the genes encoding the major 25and $36-\mathrm{kDa}$ outer-membrane proteins (OMPs) [8,9]. More recently, Bricker and Halling [10] showed that B. abortus biovars 1,2 and 4, B. melitensis, B. ovis and $B$. suis biovar 1 can be differentiated by a PCR method exploiting the polymorphism arising from species-specific localisation of the genetic element IS711 in the brucella chromosome.

The heat shock protein (hsp) DnaK belongs to the hsp70 family, which has been highly conserved during evolution [11]. The DnaK proteins possess chaperone, ATPase and initiation of DNA replication functions 
[12-17]. Recently, the dnaK gene from B. ovis has been cloned and sequenced [18]. The deduced aminoacid sequence shares $60-78 \%$ homology with that of DnaK proteins from other bacteria [18].

The present study analysed, by use of PCR-RFLP, polymorphism of the hsp dnaK locus among 77 Brucella reference and field strains representing all species with their different biovars and sought a species-specific marker on the dnaK locus of $B$. melitensis strains. B. melitensis affects mostly small ruminants and man [19] but may also affect cattle [20].

Study of polymorphism by PCR-RFLP has the advantage over Southern blot analysis in being easier to set up and less time-consuming for application to large numbers of samples. Furthermore, PCR combined with the use of species-specific markers to identify the causative agent of disease could be used for epidemiological and diagnostic purposes [21, 22].

\section{Materials and methods}

\section{Bacterial strains}

The 77 strains used in this study are listed in Table 1. All strains were kept freeze-dried in the Brucella Culture Collection, INRA, Nouzilly, France. Cultures were grown on Trypticase Soy Agar (bioMérieux, Marcy l'Etoile, France) supplemented with yeast extract (Difco Laboratories, Detroit, Michigan) $0.1 \% \mathrm{w} / \mathrm{v}$ (TSAYE medium). For fastidious strains ( $B$. abortus biovar 2 and $B$. ovis), sterile equine serum (bioMérieux) was added to TSAYE medium to a final concentration of $5 \% \mathrm{v} / \mathrm{v}$ (TSAYES medium). The strains were checked for purity and species and biovar characterisation by standard procedures [2].

\section{DNA preparation}

For each strain, a 1 -day $37^{\circ} \mathrm{C}$ culture on a TSAYE or TSAYES slope was harvested with $3 \mathrm{ml}$ of sterile distilled water, and centrifuged at $4500 \mathrm{rpm}$ for $10 \mathrm{~min}$. The pellet was suspended in $567 \mu \mathrm{l}$ of TE-Na buffer (50 mM Tris, $50 \mathrm{~mm}$ EDTA, $100 \mathrm{mM} \mathrm{NaCl}$, pH 8.0); $30 \mu \mathrm{l}$ of SDS $10 \% \mathrm{w} / \mathrm{v}$ solution and $3 \mu \mathrm{l}$ of proteinase $\mathrm{K}$ $2 \% \mathrm{w} / \mathrm{v}$ solution were then added and held at $37^{\circ} \mathrm{C}$ for $1 \mathrm{~h}$. The lysed cell suspension was extracted twice with equal volumes of a phenol-saturated solution and then chloroform. Nucleic acids were precipitated by gently mixing the resultant aqueous phase with 2 volumes of cold ethanol. The precipitate was dissolved in $100 \mu \mathrm{l}$ of TE (10 mM Tris, $1 \mathrm{mM}$ EDTA, pH 8.0). The amount of DNA was measured by electrophoresis of a sample of each preparation through agarose $0.8 \%$ gels, and comparison with standard DNA solutions.

\section{Primers}

Two 20-mer primers for the dnaK gene were obtained from Appligene (Illkirch, France). Primers were chosen to amplify the entire gene with its Shine-Dalgarno and putative transcription terminator sequences according to the B. ovis-determined dnaK gene sequence [18]. Primers used for amplification of the dnaK gene were 70A (5'-TCGAGGTCTTGGCAGTTTGC-3') and 70B (5'-TCCGTTTCATGCAGCGTGAC-3').

\section{Amplification conditions}

Amplification reactions were prepared in volumes of $100 \mu \mathrm{l}$ containing $10 \mathrm{mM}$ Tris $-\mathrm{HCl}(\mathrm{pH} 9.0), 50 \mathrm{mM}$ $\mathrm{KCl}, 1.5 \mathrm{mM} \mathrm{MgCl}_{2}$, Triton $\mathrm{X}-1000.1 \%$, gelatin $0.2 \mathrm{mg} / \mathrm{ml}(1 \times$ PCR buffer; Appligene), $200 \mu \mathrm{M}$ (each) deoxynucleoside triphosphates (dNTP), $1 \mu \mathrm{M}$ primer, $100 \mathrm{ng}$ of genomic DNA and $2.5 \mathrm{U}$ of Taq DNA Polymerase (Appligene). To reduce evaporation, the mixture was overlaid with a drop of mineral oil. The temperature cycling for amplification was performed in a Techne PHC-2 thermocycler as follows: cycle $1,95^{\circ} \mathrm{C}$ for $5 \mathrm{~min}$ (denaturation), $62^{\circ} \mathrm{C}$ for $2 \mathrm{~min}$ (annealing) and $70^{\circ} \mathrm{C}$ for $3 \mathrm{~min}$ (extension). The next 30 cycles were: $95^{\circ} \mathrm{C}$ for $1 \mathrm{~min}$ (denaturation), $62^{\circ} \mathrm{C}$ for $2 \mathrm{~min}$ (annealing) and $70^{\circ} \mathrm{C}$ for $3 \mathrm{~min}$ (extension). The last cycle was: $95^{\circ} \mathrm{C}$ for $1 \mathrm{~min}$ (denaturation), $62^{\circ} \mathrm{C}$ for $2 \mathrm{~min}$ (annealing) and $70^{\circ} \mathrm{C}$ for $10 \mathrm{~min}$ (extension).

\section{Restriction endonuclease digestion}

Restriction endonucleases were chosen according to the $B$. ovis-determined dnaK gene sequence. Fig. 1 shows the restriction map of the dnaK gene with the restriction endonucleases used. Restriction endonucleases Avall, BglII, HindIII, Hinfl, KpnI, NcoI and Pst I were purchased from Appligene; Ban I and EcoRV were purchased from Boehringer Mannheim (Germany). Five $\mu \mathrm{l}$ of PCR product were cleaved by $1-$ $5 \mathrm{U}$ of each restriction endonuclease in a reaction volume of $20 \mu \mathrm{l}$; the manufacturer's recommended buffer and incubation temperature were used.

\section{Agarose gel electrophoresis}

After amplification of the genes, $5 \mu \mathrm{l}$ of the reaction mixture or $20 \mu \mathrm{l}$ of each restriction digest were mixed with $1 \mu \mathrm{l}$ and $2 \mu \mathrm{l}$, respectively, of glycerol-dye loading buffer, and the mixture was electrophoresed in agarose gel consisting of standard quality agarose (Appligene) 1 or $1.5 \% \mathrm{w} / \mathrm{v}$ or NuSieve 3:1 agarose (TEBU, Le Perray en Yvelines, France) $2.5 \%$ and ethidium bromide (Sigma) $0.5 \mu \mathrm{g} / \mathrm{ml}$ in TBE buffer $(89 \mathrm{mM}$ Tris- $\mathrm{HCl}, 89 \mathrm{mM}$ boric acid, $2 \mathrm{mM}$ EDTA, $\mathrm{pH} 8.0$ ). The samples were electrophoresed at $20 \mathrm{~V}$ overnight on a Apelex ST 1006 electrophoresis unit. Mol. wt DNA marker VI (Boehringer Mannheim) was used as a size standard. A 254-nm UV transilluminator was used to detect the bands. 
Table 1. Brucella strains studied

\begin{tabular}{|c|c|c|c|c|c|}
\hline Study & Species & Biovar & Strain no. & Host or source & Geographic origin \\
\hline 1 & B. abortus & 1 & $544($ ATCC 23448: BCCN R4)* & Cattle & England \\
\hline 2 & B. abortus & 1 & $\mathrm{~B} 19\left(\mathrm{BCCN}\right.$ VI) ${ }^{\dagger}$ & Cattle & USA \\
\hline 3 & B. abortus & 1 & 99S (BCCN R20) & Cattle & USA \\
\hline 4 & B. abortus & 2 & $86 / 8 / 59$ (ATCC $23449 ;$ BCCN R5) & Cattle & England \\
\hline 5 & B. abortus & 3 & Tulya (ATCC 23450; BCCN R6) & Human & Uganda \\
\hline 6 & B. abortus & 4 & 292 (ATCC 23451; BCCN R7) & Cattle & England \\
\hline 7 & B. abortus & 5 & B3196 (ATCC 23452: BCCN R8) & Cattle & England \\
\hline 8 & B. abortus & 6 & 870 (ATCC 23453; BCCN R9) & Cattle & Africa \\
\hline 9 & B. abortus & 9 & C68 (ATCC $23455 ;$ BCCN R11) & Cattle & England \\
\hline 10 & B. abortus & $\mathrm{R}$ & $45 / 20(\mathrm{BCCN} \mathrm{V} 2)^{\dagger}$ & Cattle & England \\
\hline 11 & B. abortus & $\mathrm{R}$ & RB51 (BCCN V5) & Cattle & USA \\
\hline 12 & B. melitensis & 1 & 16M ATCC 23456; BCCN R1)* & Goat & USA \\
\hline 13 & B. melitensis & 1 & BCCN 93.4 & Human & France \\
\hline 14 & B. melitensis & 1 & $\mathrm{BCCN} 92.106 \mathrm{c}$ & Unknown & Algeria \\
\hline 15 & B. melitensis & 1 & BCCN 93.2 & Human & France \\
\hline 16 & B. melitensis & 1 & BCCN 88.41 & Sheep & Israel \\
\hline 17 & B. melitensis & 1 & BCCN 88.42 & Sheep & Israel \\
\hline 18 & B. melitensis & 1 & BCCN 88.43 & Human & Israel \\
\hline 19 & B. melitensis & 1 & BCCN 88.39 & Sheep & Israel \\
\hline 20 & B. melitensis & 1 & BCCN 75.477 & Dog & Israel \\
\hline 21 & B. melitensis & 1 & BCCN 75.473 & Cattle & Israel \\
\hline 22 & B. melitensis & 1 & BCCN 75.478 & Cattle & Israel \\
\hline 23 & B. melitensis & 1 & BCCN 88.44 & Human & Israel \\
\hline 24 & B. melitensis & 1 & BCCN 76.279 & Cattle & Israel \\
\hline 25 & B. melitensis & 1 & $\mathrm{BCCN} 92.70$ & Human & France \\
\hline 26 & B. melitensis & 1 & Rev. $1\left(\mathrm{BCCN} \mathrm{V}_{4} \mathrm{a}\right)^{\dagger}$ & Goat & Mexico \\
\hline 27 & B. melitensis & 1 & $\mathrm{H} 38(\mathrm{BCCN} \mathrm{V} 3)^{\dagger}$ & Human & Mexico \\
\hline 28 & B. melitensis & 1 & $\mathrm{BCCN} 90.61$ & Sheep & South Africa \\
\hline 29 & B. melitensis & 1 & BCCN 87.92 & Human & USA \\
\hline 30 & B. melitensis & 2 & 63/9 (ATCC 23457; BCCN R2) & Goat & Turkey \\
\hline 31 & B. melitensis & 3 & Ether (ATCC 23458; BCCN R3) & Goat & Italy \\
\hline 32 & B. melitensis & 3 & $\mathrm{BCCN} 83.35$ & Human & Turkey \\
\hline 33 & B. melitensis & 3 & BCCN 83.198 & Human & Spain \\
\hline 34 & B. melitensis & 3 & BCCN 90.112 & Cattle & Greece \\
\hline 35 & B. melitensis & 3 & BCCN 90.128 & Cattle & Greece \\
\hline 36 & B. melitensis & 3 & BCCN 75.472 & Cattle & Israel \\
\hline 37 & B. melitensis & 3 & BCCN 75.479 & Cattle & Israel \\
\hline 38 & B. melitensis & 3 & $\mathrm{BCCN} 92.42$ & Human & Tunisia \\
\hline 39 & B. melitensis & 3 & BCCN 92.80 & Sheep & Spain \\
\hline 40 & B. melitensis & 3 & $\mathrm{BCCN} 92.83$ & Sheep & Spain \\
\hline 41 & B. melitensis & 3 & $\mathrm{BCCN} 92.106 \mathrm{a}$ & Unknown & Algeria \\
\hline 42 & B. melitensis & 3 & BCCN 92.118 & Human & Tunisia \\
\hline 43 & B. melitensis & 3 & BCCN 92.120 & Human & Tunisia \\
\hline 44 & B. melitensis & 3 & BCCN 92.121 & Human & Tunisia \\
\hline 45 & B. melitensis & 3 & BCCN 93.3 & Human & France \\
\hline 46 & B. melitensis & 3 & BCCN 93.1 & Human & France \\
\hline 47 & B. melitensis & $\mathrm{R}$ & B115(BCCN R19) & Goat & Malta \\
\hline 48 & B. melitensis & $\mathrm{R}$ & BCCN 92.119 & Human & Tunisia \\
\hline 49 & B. melitensis & $\mathrm{R}$ & BCCN 92.116 & Sheep & France \\
\hline 50 & B. melitensis & $\mathbf{R}$ & $\mathrm{BCCN} 92.117$ & Sheep & France \\
\hline 51 & B. melitensis & $\mathbf{R}$ & BCCN 93.5 & Human & France \\
\hline 52 & B. suis & 1 & $1330(\text { ATCC } 23444 ; \text { BCCN R } 12)^{*}$ & Swine & USA \\
\hline 53 & B. suis & 1 & S2 (BCCN V6) & Swine & China \\
\hline 54 & B. suis & 2 & Thomsen (ATCC 23445; BCCN R13) & Swine & Denmark \\
\hline 55 & B. suis & 3 & 686 (ATCC 23446; BCCN R14) & Swine & USA \\
\hline 56 & B. suis & 4 & 40 (ATCC 23447; BCCN R15) & Reindeer & Former Soviet Union \\
\hline 57 & B. suis & 5 & $513(\mathrm{BCCN} \mathrm{R} 21)$ & Wild rodent & Former Soviet Union \\
\hline 58 & B. ovis & & 63/290 (ATCC 25840; BCCN R17)* & Sheep & Africa \\
\hline 59 & B. ovis & & Reo 198 (BCCN R22) & Sheep & USA \\
\hline 60 & B. ovis & & BCCN 76.247 & Sheep & France \\
\hline 61 & B. ovis & & BCCN 76.250 & Sheep & France \\
\hline 62 & B. ovis & & $\mathrm{BCCN} 91.66$ & Sheep & Spain \\
\hline 63 & B. ovis & & BCCN 91.70 & Sheep & Spain \\
\hline 64 & B. ovis & & BCCN 91.208 & Sheep & Spain \\
\hline 65 & B. ovis & & $\mathrm{BCCN} 91.212$ & Sheep & Spain \\
\hline 66 & B. ovis & & $\mathrm{BCCN} 91.217$ & Sheep & Spain \\
\hline 67 & B. ovis & & BCCN 91.264 & Sheep & Argentina \\
\hline 68 & B. ovis & & BCCN 91.266 & Sheep & Argentina \\
\hline 69 & B. ovis & & BCCN 91.268 & Sheep & Switzerland \\
\hline 70 & B. canis & & RM6/66 (ATCC 23365; BCCN R18)* & Dog & USA \\
\hline 71 & B. canis & & BCCN 87.62 & Unknown & Mexico \\
\hline 72 & B. canis & & BCCN 87.66 & Dog & Canada \\
\hline 73 & B. canis & & $\mathrm{BCCN} \mathrm{C} 2$ & Dog & USA \\
\hline 74 & B. canis & & $\mathrm{BCCN} \mathrm{C3}$ & Dog & USA \\
\hline 75 & B. canis & & $\mathrm{BCCN} \mathrm{C1}$ & Dog & Madagascar \\
\hline 76 & B. canis & & $\mathrm{BCCN} \mathrm{C} 4$ & Dog & USA \\
\hline 77 & B. neotomae & & $5 \mathrm{~K} 33$ (ATCC 23459 ; BCCN R16) & Desert wood rat & USA \\
\hline
\end{tabular}

ATCC, American Type Culture Collection, Rockville, MD; BCCN, Brucella Culture Collection, Nouzilly (France).

${ }^{*}$ Reference strains.

tVaccine strains. 


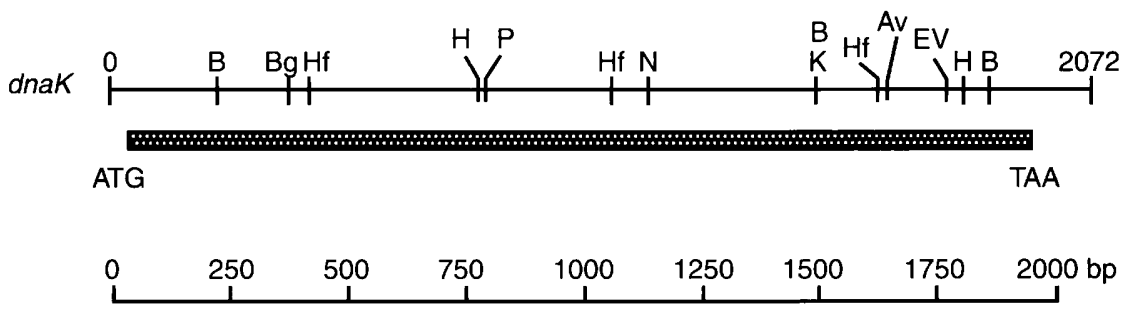

Fig. 1. Restriction map of the PCR-amplified dnaK gene, according to the gene sequence determined from $B$. ovis by Cellier et al. [18]. The coding sequence is shown by a shaded rectangle under the restriction map. Restriction sites are indicated as follows: Av, AvaII; B, Ban I; Bg, BglII; EV, EcoRV; H, HindIII; Hf, HinfI; K, KpnI; N, NcoI; P, PstI.

\section{Southern blot}

PCR-amplified dnaK gene from B. melitensis $16 \mathrm{M}$ was purified by the GeneClean procedure (Bio 101, La Jolla, CA, USA) and labelled with the random priming PolarPlex kit (Millipore, Bedford, MA, USA) for use as probe in the Southern blot hybridisation. Whole genomic DNA $(2-5 \mu \mathrm{g})$ from Brucella strains was digested with EcoRV and run on SeaKem agarose (FMC, Rockland, ME, USA) $0.8 \%$ gel in TBE buffer. The fragments were transferred to a nylon Immobilon$S$ membrane (Millipore) by vacuum transfer by the VacuGene System (Pharmacia LKB Biotechnology, Uppsala, Sweden). Hybridisation and detection reactions were performed according to the PolarPlex protocol. Biotinylated Lambda/HindIII and Phi X 174/Hae III digests (Millipore) were used as mol. wt DNA markers.

\section{DNA sequencing}

The dideoxy chain termination method of Sanger et al. [23] was employed with the SequiTherm ${ }^{\mathrm{TM}}$ Cycle Sequencing Kit (Epicentre Technologies, Madison, WI, USA) according to the manufacturer's protocol. PCRamplified dnaK genes from $B$. ovis and B. melitensis were purified from an agarose gel with the GeneClean kit (Bio 101) and used as templates, and primer 70B was used for annealing in the sequencing reaction. The temperature cycling for the amplification was performed in a Techne PHC-2 thermocycler as follows: cycle $1,95^{\circ} \mathrm{C}$ for $5 \mathrm{~min}$ (denaturation), $50^{\circ} \mathrm{C}$ for $30 \mathrm{~s}$ (annealing) and $70^{\circ} \mathrm{C}$ for $1 \mathrm{~min}$ (extension). The next 30 cycles were: $95^{\circ} \mathrm{C}$ for $30 \mathrm{~s}$ (denaturation), $50^{\circ} \mathrm{C}$ for $30 \mathrm{~s}$ (annealing) and $70^{\circ} \mathrm{C}$ for $1 \mathrm{~min}$ (extension).

\section{Results}

\section{$P C R-R F L P$}

Fig. 1 shows the restriction map of the PCR-amplified dnaK locus comprising the ribosome binding site, open reading frame and transcription terminator sequences, according to the DNA sequence determined from $B$. ovis [18], with restriction endonucleases Ava II, Ban I, $B g l$ II, Eco RV, HindIII, Hin fI, Kpn I, Nco I, Pst I used for RFLP study. The PCR-amplified dnaK loci from the six Brucella species reference strains - B. abortus 544 (biovar 1), B. melitensis 16M (biovar 1), B. suis 1330 (biovar 1), B. ovis 63/290, B. canis RM6/66 and B. neotomae $5 \mathrm{~K} 33$ - showed identical restriction patterns with AvaII, BanI, BglII, HindIII, Hinfl, Kpn I, NcoI and Pst I, which corresponded to restriction patterns of the published $B$. ovis dnaK sequence (Fig. 2, and data not shown). A distinct restriction pattern of the dnaK locus from B. melitensis $16 \mathrm{M}$ was observed with EcoRV; there was a single EcoRV site 'EcoRV (1767)' instead of two EcoRV sites for dnaK

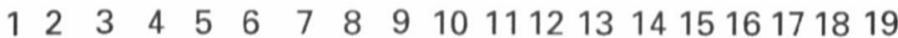

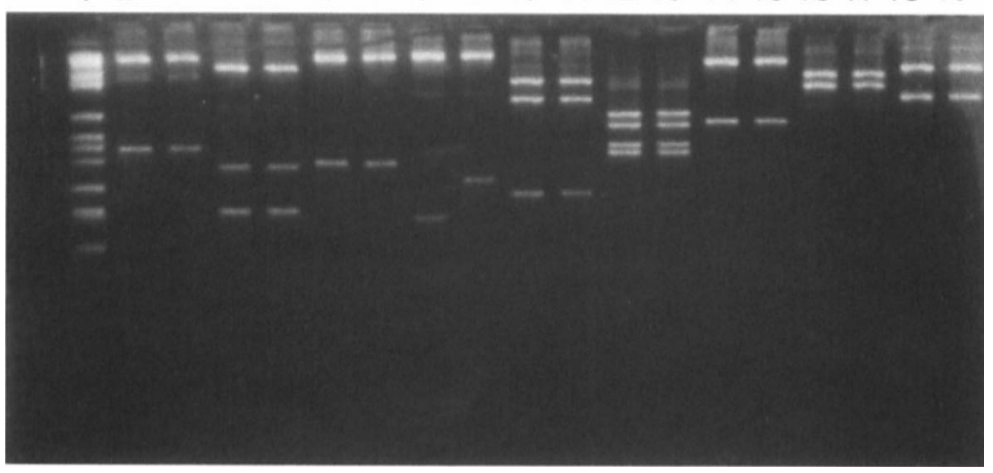

Fig. 2. Electrophoretic analysis of PCR-amplified dnaK genes of $B$. ovis $63 / 290$ (lanes 2, 4, 6, 8, 10, 12, 14, 16, 18) and $B$. melitensis $16 \mathrm{M}(3,5,7,9,11,13,15,17,19)$ digested with $A v a \mathrm{II}(2$ and 3), Ban I (4 and 5), BglII (6 and 7), EcoRV (8 and 9), HindIII (10 and 11), HinfI (12 and 13), KpnI (14 and 15), Nco I (16 and 17), PstI (18 and 19); lane 1, DNA mol. wt marker VI (Boehringer, Mannheim) 2176, 1766, 1230, 1033, 653, 517, 453, 394, 298, 234, 220, $154 \mathrm{bp}$. 
genes of the other Brucella species (Fig. 2). However, the EcoRV pattern for the dnaK gene of B. ovis $63 / 290$ did not correspond to that of the published $B$. ovis dnaK nucleotide sequence [18]. According to the published nucleotide sequence [18], only one EcoRV site is present at the dnaK locus of $B$. ovis at the same position as that of $B$. melitensis. Therefore, study by PCR-RFLP of the dnaK locus with EcoRV was extended to a large number of Brucella reference, vaccinal and field strains from different geographic origins and hosts, listed in Table 1. The presence of the unique EcoRV site in the $d n a K$ locus was specific to $B$. melitensis strains. All other Brucella strains, including $B$. ovis strains, showed the presence of two $E c o$ RV sites in their $d n a K$ sequences as shown for that of B. ovis 63/290 in Fig. 2.

\section{Southern blot analysis}

Southern blot analysis of whole genomic DNA from Brucella species digested with EcoRV was performed with the PCR-amplified dnaK gene as probe to confirm the specific pattern of $B$. melitensis. A single band, positioned at $c$. $2300 \mathrm{bp}$, was detected for EcoRV-digested DNA from $B$. abortus $544, B$. suis $1330, B$. ovis 63/290, B. canis RM6/66 and $B$. neotomae 5K33 (Fig. 3), whereas two bands, one at the same position as the band of the former strains and a second less strongly stained band of higher mol. wt (around $3000 \mathrm{bp}$ ), were detected for the type strains of the three B. melitensis biovars $-B$. melitensis $16 \mathrm{M}$ (biovar 1), B. melitensis 63/9 (biovar 2) and $B$. melitensis Ether (biovar 3) (Fig. 3).

\section{DNA sequence analysis}

The presence of the second EcoRV site located at the $3^{\prime}$ end of the PCR-amplified dnaK gene of B. ovis 63/ 290 was confirmed by DNA sequence analysis. This EcoRV site was located outside the dnaK open reading frame, between the stop codon and the putative transcription terminator sequence, in a $12 \mathrm{bp}$ segment that was missing in the published $d n a K$ sequence of $B$. ovis [18] (Fig. 4). A supplementary base-pair (Fig. 4) occurred in the 12-bp segment of $B$. melitensis $16 \mathrm{M}$, explaining the lack of the $E c o$ RV site in this species and its specific pattern seen in PCR-RFLP and Southern blot analysis.

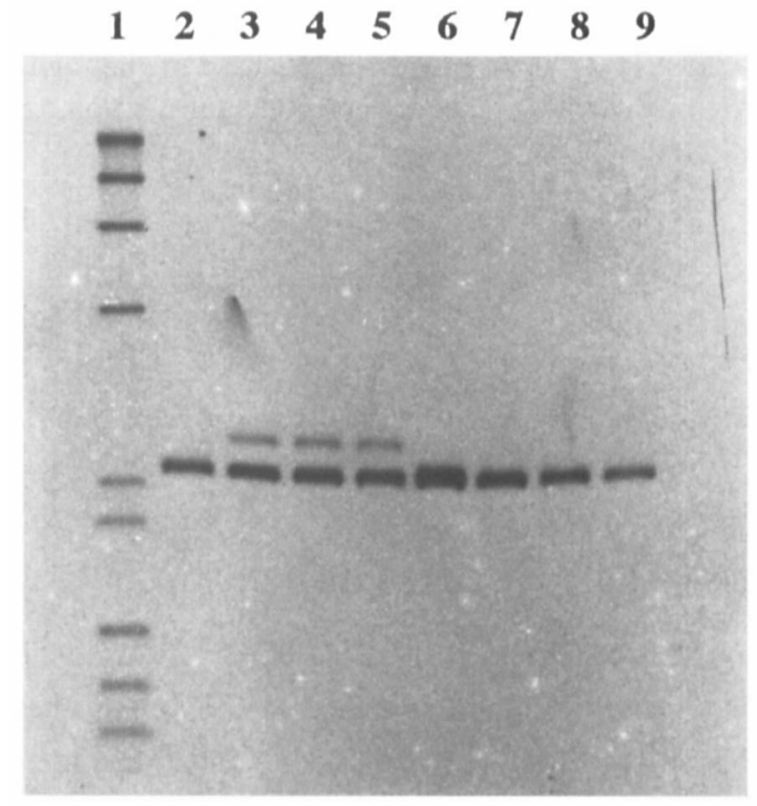

Fig. 3. Southern blot analysis of Brucella DNA cut with EcoRV. PCR-amplified dnaK gene of B. melitensis 16M was used as probe. Lane 1: DNA mol. wt marker, fragment sizes are 23130, 9416, 6557, 4361, 2322, 2027, 1353, 1078, $872 \mathrm{bp}$; 2: B. abortus 544 (biovar 1) DNA; 3: B. melitensis 16M (biovar 1) DNA; 4: B. melitensis 63/9 (biovar 2) DNA; 5: B. melitensis Ether (biovar 3) DNA; 6: B. suis 1330 (biovar 1) DNA; 7: B. ovis 63/290 DNA; 8: B. canis RM6/66 DNA; 9: B. neotomae 5K33 DNA.

\section{Discussion}

Polymorphism at the dnaK locus among Brucella species was studied by PCR-RFLP and Southern blot analysis. As expected from the point of view of conservation of DnaK protein among different genera and the fact that Brucella constitutes a homogeneous group according to DNA-DNA hybridisation [3], the dnaK gene seemed to be highly conserved among Brucella species. More gene polymorphism was detected for, instance, in the major Brucella 25- and $36-\mathrm{kDa}$ (porin) OMP genes $[8,9]$ which are probably more variable in relation to host environment. Nevertheless, the species-specific polymorphism found with $E c o$ RV at the dnaK locus of $B$. melitensis strains is interesting for typing, epidemiological and diagnostic purposes and may be complementary to other speciesspecific markers previously detected in other genes $[8,9]$. It is interesting to note that these speciesspecific markers, found for instance at the dnaK locus

\section{B. melitensis $16 \mathrm{M}$}

\section{B. ovis $63 / 290$}

\section{CCCGGGGAATATCCCCGGG}

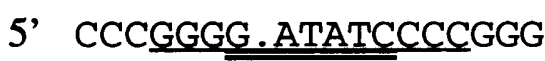

3'

Fig. 4. Location of the EcoRV polymorphic site by DNA sequence analysis of PCR-amplified dnaK of $B$. ovis $63 / 290$ and $B$. melitensis $16 \mathrm{M}$. The EcoRV site was located between the stop codon and putative transcription terminator sequence of dnaK. The position number 2378 corresponds to that of the $B$. ovis dnaK sequence published by Cellier et al. [18]. The $12 \mathrm{bp}$ segment missing in this sequence is underlined. The EcoRV site is double underlined. The absence in $B$. ovis $63 / 290$ of the additional base-pair present in $B$. melitensis $16 \mathrm{M}$ is indicated by a point. 
in the present study, are due to an additional single base-pair in $B$. melitensis, or in the case of the omp 25 gene [8] due to one single nucleotide substitution, and that these markers are remarkably conserved within species. However, the simultaneous use of several species-specific markers must still be considered on a large number of strains before one or more of them can routinely be used for typing purposes.

The result of the presence of an additional base-pair at the dnaK locus of $B$. melitensis compared with the other Brucella species may contribute, as with previous studies focused on Brucella gene polymorphism $[8,9]$, to the understanding of the phylogeny of Brucella spp. Indeed, if the excision was considered to have occurred in the other Brucella species, $B$. melitensis might represent the progenitor species of the others. This idea is also supported by the study of omp $2 b$ porin gene polymorphism by PCR-RFLP, in which hypothetical Brucella phylogenetic networks were established based on single mutational events [8]

Although a single species concept may be considered for Brucella on the basis of DNA-DNA homology [3], it is still important for epidemiological purposes to distinguish between the defined Brucella species on the basis of their differential host preference. $B$. melitensis strains are most often isolated from small ruminants like sheep and goats, but in some areas where $B$. melitensis is highly prevalent, infection of cattle, which are more usually infected by $B$. abortus, has also been reported [20]. Consequently, it is important to know the causative agent of infection for establishing prophylactic and eradication schemes. The contribution of molecular biology to the identification of species-specific markers and methods like PCR may greatly facilitate and hasten the identification of Brucella strains.

We are grateful to G. Dubray for reading of the manuscript critically. We thank N. Vizcaino for collaboration. A. Cloeckaert was supported by a CEC fellowship.

\section{References}

1. Corbel MJ, Brinley-Morgan WJ. Genus Brucella Meyer and Shaw 1920, 173 AL . In: Krieg NR, Holt JG (eds) Bergey's Manual of systematic bacteriology, vol 1. Baltimore, Williams and Wilkins Co. 1984: 377-388.

2. Alton GG, Jones LM, Angus RD, Verger JM. Techniques for the brucellosis laboratory. Paris, Institut National de la
Recherche Agronomique. 1988.

3. Verger J-M, Grimont F, Grimont PAD, Grayon M. Brucella, a monospecific genus as shown by deoxyribonucleic acid hybridization. Int J Syst Bacteriol 1985; 35: 292-295.

4. Verger J-M, Grimont F, Grimont PAD, Grayon M. Taxonomy of the genus Brucella. Ann Inst Pasteur/Microbiol 1987; 138: 235-238.

5. Allardet-Servent A, Bourg G, Ramuz M, Pages M, Bellis M, Roizes G. DNA polymorphism in strains of the genus Brucella. J Bacteriol 1988; 170: 4603-4607.

6. Fekete A, Bantle JA, Halling SM, Stich RW. Amplification fragment length polymorphism in Brucella strains by use of polymerase chain reaction with arbitrary primers. $J$ Bacteriol 1992; 174: 7778-7783.

7. Grimont F, Verger J-M, Cornelis $\mathrm{P}$ et al. Molecular typing of Brucella with cloned DNA probes. Res Microbiol 1992; 143: 55-65.

8. Cloeckaert A, Verger J-M, Grayon M, Grépinet O. Restriction site polymorphism of the genes encoding the major $25 \mathrm{kDa}$ and $36 \mathrm{kDa}$ outer-membrane proteins of Brucella. Microbiology 1995; 141: 2111-2121.

9. Ficht TA, Bearden SW, Sowa BA, Marquis H. Genetic variation at the omp2 porin locus of the brucellae: speciesspecific markers. Mol Microbiol 1990; 4: 1135-1142.

10. Bricker BJ, Halling SM. Differentiation of Brucella abortus bv. 1, 2, and 4, Brucella melitensis, Brucella ovis, and Brucella suis bv. 1 by PCR. J Clin Microbiol 1994; 32: 2660-2666.

11. Lindquist S, Craig EA. The heat-shock proteins. Annu Rev Genet 1988; 22: 631-677.

12. Georgopoulos CP. A new bacterial gene (groPC) which affects lambda DNA replication. Mol Gen Genet 1977; 151: 35-39.

13. Langer T, Lu C, Echols H, Flanagan J, Hayer MK, Hartl FU. Successive action of DnaK, DnaJ and GroEL along the pathway of chaperone-mediated protein folding. Nature 1992; 356: 683-689.

14. McCarty JS, Walker GC. DnaK as a thermometer: threonine199 is site of autophosphorylation and is critical for ATPase activity. Proc Natl Acad Sci USA 1991; 88: 9513-9517.

15. Sakakibara Y. The dnaK gene of Escherichia coli functions in initiation of chromosome replication. J Bacteriol 1988; 170: 972-979.

16. Sozhamannan S, Chattoraj DK. Heat shock proteins DnaJ, DnaK, and GrpE stimulate P1 plasmid replication by promoting initiator binding to the origin. J Bacteriol 1993; 175: $3546-3555$

17. Tilly K, Yarmolinsky M. Participation of Escherichia coli heat shock proteins DnaJ, DnaK, and GrpE in Pl plasmid replication. J Bacteriol 1989; 171: 6025-6029.

18. Cellier MFM, Teyssier J, Nicolas M, Liautard JP, Marti J, Sri Widada J. Cloning and characterization of the Brucella ovis heat shock protein DnaK functionally expressed in Escherichia coli. J Bacteriol 1992; 174: 8036-8042.

19. Alton GG. Brucella melitensis. In: Nielsen K, Duncan JR (eds) Animal brucellosis. Boca Raton, FL, CRC Press, Inc. 1990: $383-409$.

20. Verger JM. B. melitensis infection in cattle. In: Verger JM, Plommet $\mathrm{M}$ (eds) Brucella melitensis. Dordrecht, MartinusNijhoff. 1985: 197-203.

21. Fekete A, Bantle JA, Halling SM, Sanborn MR. Preliminary development of a diagnostic test for Brucella using polymerase chain reaction. J Appl Bacteriol 1990; 69: 216-227.

22. Herman L, De Ridder H. Identification of Brucella spp. by using the polymerase chain reaction. Appl Environ Microbiol 1992; 58: 2099-2101.

23. Sanger F, Nicklen S, Coulson AR. DNA sequencing with chain-terminating inhibitors. Proc Natl Acad Sci USA 1977; 74: $5463-5467$. 